\title{
Nieodpowiedzialność a niemoralność działań przedsiębiorstw. Perspektywa teorii kodów moralnych
}

\section{Streszczenie}

Działania przedsiębiorstw, podobnie jak innych organizacji, są oceniane przez interesariuszy pod względem poziomu ich etyczności. Wynik takiej oceny może być pozytywny albo negatywny. Dotychczasowa literatura przedmiotu zdominowana jest przez prace skupiające się na aspektach pozytywnych. Relatywnie niewiele uwagi poświęca się nieodpowiedzialnym praktykom, chociaż ich konsekwencje są często bardzo poważne. Dążąc do lepszego zrozumienia istoty działań przedsiębiorstw wskazywanych przez konsumentów jako społecznie nieodpowiedzialne, za cel niniejszego artykułu przyjęto określenie relacji między nieodpowiedzialnością a niemoralnością działań przedsiębiorstw. Zmierzając do osiągnięcia takiego celu, za ramy koncepcyjne przyjęto teorię kodów moralnych. W dyskusji zwracano szczególną uwagę na badania empiryczne pokazujące znaczenie poszczególnych kryteriów oceny moralności działań przedsiębiorstwa. Część empiryczną stanowią wyniki badań eksploracyjnych, w których podjęto próbę przyporządkowania nieodpowiedzialnych praktyk przedsiębiorstw do pięciu kodów moralnych. Uzyskane wyniki sugerują, że nieodpowiedzialne praktyki wiążą się najczęściej

Dr hab. Grzegorz Zasuwa, adiunkt w Katedrze Zarządzania Pracownikami w Organizacji w Instytucie Dziennikarstwa i Zarządzania na Wydziale Nauk Społecznych Katolickiego Uniwersytetu Lubelskiego Jana Pawła II; e-mail: grzegorz.zasuwa@kul.pl; ORCID: 0000-0003-4131-5079. 
z nieuczciwością i wyrządzaną krzywdą interesariuszom. Zdecydowanie rzadziej wskazywane są przez konsumentów zachowania dotyczące nielojalności, łamania prawa i opresyjności. Tekst kończy dyskusja wyników zawierająca implikacje teoretyczne, wnioski praktyczne oraz ograniczenia i kierunki dalszych badań.

Słowa kluczowe: społeczna nieodpowiedzialność przedsiębiorstw, teoria kodów moralnych, nieetyczne zachowania przedsiębiorstw

\section{Wprowadzenie}

Po wielu latach znacznego zainteresowania problematyką społecznej odpowiedzialności uwaga badaczy kieruje się w stronę tematyki nieodpowiedzialności przedsiębiorstw. Szeroko nagłośnione skandale dotyczące największych korporacji na świecie, np. unikanie płacenia podatków przez Amazon (Ethical Consumer, 2021), wyraźnie pokazały, że działania przedsiębiorstw nie są zawsze uczciwe i korzystne dla społeczeństwa. Część badaczy twierdzi nawet, m.in. Duane Windsor z Rice University, iż straty z tytułu szkodliwych działań przedsiębiorstw są znacznie większe niż korzyści wynikające z ich działań prospołecznych i proekologicznych (Windsor, 2013). Trzeba także dodać, że nieetyczne działania przedsiębiorstw mogą być przyczyną strat dla nich samych. Wskazuje na to przykład disealgate, kiedy to wartość rynkowa akcji koncernu Volkswagen zmniejszyła się o $23 \%$ po upublicznieniu informacji o celowym fałszowaniu danych na temat emisji spalin (Bloomberg, 2015).

Chociaż nieodpowiedzialne praktyki przedsiębiorstw niosą ze sobą istotne implikacje dla społeczeństwa oraz samych przedsiębiorstw, wiedza na ten temat jest na relatywnie wczesnym etapie rozwoju. Odnośnie do samej koncepcji społecznej nieodpowiedzialności szereg prac wskazuje, iż należy ją traktować jako odrębne zjawisko od społecznej odpowiedzialności. Innymi słowy - badacze skłaniają się ku stanowisku, że rozpatrywanie w jednym wymiarze działań odpowiedzialnych i nieodpowiedzialnych jako skrajnych punktów znajdujących się na jednej osi nie oddaje w pełni różnic między tymi zjawiskami (Clark, Riera, Iborra, 2021; Jones, Bowd, Tench, 2009). Mimo to pozostaje jeszcze wiele pytań w kwestii samej natury społecznej nieodpowiedzialności oraz jej związków z innymi koncepcjami.

Dążąc do lepszego poznania idei społecznej nieodpowiedzialności oraz jej relacji z innymi teoriami funkcjonującymi w obszarze szeroko pojętej etyki biznesu, za cel niniejszego artykułu przyjęto określenie relacji między nieodpowiedzialnością a niemoralnością działań przedsiębiorstw. Zważywszy, że tematyka etyki i moralności jest niezwykle rozległym obszarem, sięgającym swoimi korzeniami filozofii starożytnej, rozważania w niniejszym tekście ograniczone zostaną do teorii kodów 
moralnych (ang. Moral Foundations Theory), zainicjowanej przez Jonathana Haidta i Craiga Josepha w 2004 roku (Haidt, Joseph, 2004).

Wyboru teorii kodów moralnych jako ram, w których prowadzone są analizy, dokonano z dwóch powodów. Po pierwsze, wielu badaczy, wyjaśniając, czym jest społeczna nieodpowiedzialność przedsiębiorstw, wskazuje na niemoralność jako jeden z kluczowych wyróżników tego pojęcia. Przy czym autorzy podają różne czynniki, z których wynika negatywna ocena działania przedsiębiorstwa pod względem moralnym. Najczęściej podawaną przyczyną takiej oceny jest wyrządzona krzywda interesariuszom (Campbell, 2007; Hoi, Wu, Zhang, 2013; Lange, Washburn, 2012; Lin-Hi, Müller, 2013; Mena i in., 2016). Poza wspomnianą krzywdą wskazuje się także na inne cechy niemoralnych działań, wśród których wyróżnia się: brak poszanowania przepisów prawa (Bianchi, Mohliver, 2016; Oh, Chang, Jung, 2018), stosowanie manipulacji i oszustw (Greenwood, 2007) oraz lekceważenie interesariuszy (Pearce, Manz, 2011). Teoria kodów moralnych, przyjmując założenie o różnych wymiarach niemoralności, może stanowić komplementarne ramy koncepcyjne w stosunku do nieodpowiedzialności przedsiębiorstw. Po drugie, teoria kodów moralnych łączy ocenę etyczności zachowania z emocjami (Haidt, 2001). Ostatnie badania prowadzone nad reakcjami interesariuszy (głównie konsumentów) wobec przedsiębiorstw stosujących nieodpowiedzialne praktyki pokazują, że istotną rolę w wyjaśnianiu zachowań mających na celu karanie przedsiębiorstw odgrywają uczucia interesariuszy wywołane informacjami o stosowaniu wspomnianych praktyk (Antonetti, 2020). Lepsze poznanie związków między nieodpowiedzialnością przedsiębiorstw a kodami moralnymi może więc przyczynić się do pełniejszego wyjaśnienia zachowań interesariuszy wobec nieodpowiedzialnych społecznie przedsiębiorstw.

W warstwie empirycznej relacje między kodami moralnymi a nieodpowiedzialnością analizowane są na podstawie opinii zgromadzonych podczas zogniskowanych wywiadów pogłębionych z konsumentami. Ujawnione w trakcie badań praktyki przedsiębiorstw uporządkowane są względem wiodących kodów moralnych i poddane dyskusji.

\section{Ramy teoretyczne i przegląd literatury}

Przedstawiając zarys teorii kodów moralnych, warto wspomnieć o ich naturze. Zdaniem Haidta i współpracowników są to pewnego rodzaju intuicje czy też predyspozycje moralne, wykształcone w toku ewolucji (ang. innate moral codes), które posiada każdy człowiek (Graham i in., 2013). Znaczenie tych kryteriów nie jest jednak jednakowe u wszystkich ludzi, bowiem odpowiednią rangę, wyższą bądź niższą, 
zyskują one pod wpływem uwarunkowań, w jakich człowiek dorasta i funkcjonuje. Jako przykład wspomnianych różnic zespół Haidta podaje, że mieszkańcy Brazylii stosują szerszy wachlarz kryteriów oceny moralnej, przykładając większe znaczenie do lojalności oraz autorytetu niż zamożni mieszkańcy Stanów Zjednoczonych, których oceny moralne opierają się przede wszystkim na dostrzeganej krzywdzie i niesprawiedliwości (Graham i in., 2013). Występowanie istotnych różnic między ludźmi w zakresie moralności potwierdzają także prace porównujące moralność między państwami postkomunistycznymi a krajami o dojrzałych gospodarkach rynkowych (Pawlak, 2018, 2019; Payne, Pawlak, Mahesh, 2018).

Wyjaśniając, w jaki sposób powstają sądy moralne, teoria kodów moralnych przyjmuje stanowisko intuicjonizmu społecznego (Graham i in., 2013). Zgodnie z tym podejściem oceny moralne podobne są do sądów estetycznych, które w automatyczny sposób powstają poza świadomością obserwatora. Haidt (2001) pisze, że przy ocenach moralnych zwykle od razu wiemy, czy coś jest dobre czy złe, analogicznie jak w przypadku oceny sztuki wiemy, czy coś się nam podoba (jest piękne) czy się nam nie podoba (jest brzydkie). Świadoma i pogłębiona refleksja nad danym sądem może przyjść później, gdy uzasadniamy nasze oceny (Haidt, 2001). W ten sposób Haidt i współpracownicy przyznają pierwszeństwo intuicji przed podejściem racjonalistycznym, które głosi, że człowiek w obiektywny i w pełni świadomy sposób dokonuje oceny zdarzenia pod względem etycznym (Graham i in., 2013). Nie mniej jednak teoria kodów moralnych nie neguje istnienia świadomej oceny moralnej. Wskazuje ona jednak, że pierwsza ocen moralna ma automatyczny i intuicyjny charakter, będąc wypadkową kryteriów oceny (kodów moralnych), cech postrzeganego czynu oraz emocji, jakie odczuwa jednostka wobec sprawcy. Zgodnie z tą teorią kolejna, świadoma faza oceny moralnej jest zazwyczaj uzasadnieniem pierwotnie powstałego sądu, jej celem nie jest więc dążenie do poznania obiektywnej prawdy, ale obrona intuicyjnego sądu (Haidt, 2001).

Tak jak zaznaczono we wprowadzeniu, teoria kodów moralnych stoi na stanowisku pluralizmu moralnego, co oznacza, że istnieje wiele kryteriów, na podstawie których ludzie dokonują oceny zachowań pod względem etycznym (Haidt, Joseph, 2004). Haidt i współpracownicy wskazują, że ludzie dokonują oceny moralnej nie tylko na podstawie dostrzeganej troski bądź krzywdy (ang. care/harm foundation) w rozpatrywanym działaniu, tak jak przyjmuje się w monistycznych koncepcjach etyki, ale biorą pod uwagę także inne wyznaczniki moralności. Do najlepiej poznanych oraz mających największe znaczenie kryteriów moralności twórcy teorii kodów moralnych zaliczają: sprawiedliwość/oszukaństwo (ang. fairness/cheating), lojalność/zdradę (ang. loyalty/betrayl), autorytet/przewrót (ang. authority/subversion) oraz czystość (świętość)/degradację (ang. sanctity/degradation). Zgodnie ze wspomnianą teorią katalog ten nie jest zamknięty, w zależności od uwarunkowań 
może on obejmować także inne cechy zachowań, które sprawiają, że dane zdarzenie oceniane jest jako dobre albo złe pod względem moralnym.

Badając związki społecznej nieodpowiedzialności z teorią kodów moralnych, w pierwszej kolejności sprawdzono, które z nich pojawiają się w dotychczasowych badaniach nad reakcjami interesariuszy wobec nieodpowiedzialności przedsiębiorstw. Wspomniane rozważania ograniczone są do reakcji konsumentów, zważywszy, iż część empiryczna niniejszego tekstu wykorzystuje opinie wymienionej grupy. Mając na uwadze fakt, że teoria kodów moralnych w oryginalnej wersji dotyczyła ocen zachowań ludzi w życiu codziennym, w prezentowanym artykule podjęto próbę dostosowania kryteriów oceny moralnej do przedsiębiorstw jako szczególnej kategorii podmiotów, których działania poddawane są ocenie etycznej. Takie podejście jest zgodne z poglądami prezentowanymi w literaturze przedmiotu, gdzie wskazuje się, iż różne wartości mogą stanowić podstawę sądów moralnych w zależności od sytuacji (Schein, Gray, 2018).

Krzywda

Pierwszym, powszechnie uznawanym przez badaczy kryterium oceny moralnej działania jest krzywa. Haidt i współpracownicy zestawiają krzywdę z troską, wskazując, że troska ma na celu ochronę jednostki przed wyrządzeniem jej krzywdy. Krzywda nie jest jednak dokładnie zdefiniowana na gruncie teorii kodów moralnych. Analizując treść kwestionariusza do pomiaru kodów moralnych, można dostrzec, iż krzywda wiąże się tutaj z okrucieństwem i cierpieniem zarówno w ujęciu fizycznym, jak i psychicznym, i dotyczyć może ona ludzi oraz zwierząt (Graham $i$ in., 2011).

Wielu badaczy zajmujących się szeroko pojętą etyką biznesu wskazuje, że krzywda to jedna z kluczowych cech nieodpowiedzialnego działania przedsiębiorstwa. Na przykład Nick Lin-Hi i Karsten Müller (2013) wyjaśniają, że nieodpowiedzialne działania przedsiębiorstw to takie, które prowadzą do realnych albo potencjalnych niekorzyści lub szkód wyrządzanych innym podmiotom. W badaniach konsumenckich szkoda także należy do najczęściej rozpatrywanych zjawisk wywołujących negatywne emocje i inne wrogie zachowania wobec nieodpowiedzialnych przedsiębiorstwa (Antonetti, Maklan, 2016b; Ingram, Skinner, Taylor, 2005; Yuksel, Mryteza, 2009). Warto tutaj także wspomnieć, że oznaką wymienionej szkodliwości jest zwykle cierpienie pokrzywdzonych interesariuszy (Goetz, Keltner, Simon-Thomas, 2010).

\section{Nieuczciwość}

Kolejne kryterium oceny działania pod względem moralnym stanowi nieuczciwość. Haidt i współpracownicy (Graham i in., 2013) wyjaśniają, że wśród 
oznak nieuczciwości można wyróżnić oszukiwanie oraz stosowanie manipulacji w kontaktach z innymi ludźmi. Dostrzegana nieuczciwość w działaniu ocenianej osoby traktowana jest jako czynnik komplementarny w stosunku do postrzeganej krzywdy, ponieważ wyrządzana krzywda innej osobie niekoniecznie musi zostać oceniona negatywnie pod względem moralnym. Na przykład w sytuacji, gdy ktoś sobie zasłuży na karę, krzywda może zostać zaakceptowana (Sousa, Piazza, 2014). Dlatego też krzywdę i nieuczciwość traktuje się jako dwa podstawowe kryteria oceny moralnej rozpatrywanego czynu (Graham i in., 2013).

W literaturze z zakresu odpowiedzialności znajdujemy relatywnie niewiele informacji o znaczeniu krzywdy dla interesariuszy (w tym konsumentów) oraz jej konsekwencjach. Wśród nielicznych badań na ten temat Paolo Antonetti i Stan Maklan (2016a) wykazali, że nieuczciwość przedsiębiorstwa potęguje dostrzegana w jego działaniu chciwość. Wiadomo także, iż osoby cechujące się wysokimi oczekiwaniami etycznymi wobec przedsiębiorstw mają tendencję do dostrzegania większej nieuczciwości w ich działaniach (Ferrell i in., 2019; Kim, Krishna, Dhanesh, 2019).

\section{Nielojalność}

Następnym kryterium wydawania sądów moralnych w teorii proponowanej przez Haidta jest lojalność (nielojalność). Podobnie jak wcześniejsze kryteria oceny zachowań, jej znaczenie wynika z potrzeby nawiązywania i utrzymywania współpracy między ludźmi. Brak lojalności wobec grupy, w której funkcjonuje jednostka, utrudnia jej efektywność (Graham i in., 2013).

Według autora problematyka lojalności przedsiębiorstw wobec konsumentów $\mathrm{i}$ innych grup interesariuszy jest rzadko podejmowana w literaturze przedmiotu. To czy przedsiębiorstwo postępuje lojalnie wobec swoich partnerów, pojawia się pośrednio w zaufaniu albo jego braku ze strony interesariuszy, np. gdy ujawniają się wady produktu. Poza tym, że lojalność pojawia się tylko pośrednio, to jeszcze dodatkowo punk ciężkości przez cały czas skupia się na konsumencie, który ma być lojalny wobec przedsiębiorstw i jego produktów. Mając na uwadze fakt, iż dążenie do zachowania rentowności ma fundamentalne znaczenie dla przedsiębiorstw, skupienie uwagi na konsumencie jest racjonalne. Jednak z szerszej, społecznej perspektywy wydaje się, że warto także rozważyć, czy wszystkie działania przedsiębiorstw wobec zarówno swoich klientów, jak i innych interesariuszy są zawsze lojalne.

\section{Nielegalność}

W oryginalnej wersji teorii kodów moralnych kolejnym kryterium jest poszanowanie autorytetu. Haidt i współpracownicy piszą, że w społeczeństwie (a nawet i pewnych grupach zwierząt) występują zhierarchizowane struktury. Osoby, które je respektują, mogą zyskać przewagę nad tymi, którzy nie oddają należytego szacunku 
osobom znajdującym się na szczycie takiej struktury. Brak poszanowania autorytetu może także spotkać się z negatywnymi konsekwencjami ze strony grupy, w której funkcjonuje jednostka (Graham i in., 2013).

Odnosząc normę poszanowania autorytetu do zachowań przedsiębiorstw, warto zauważyć, że przedsiębiorstwa funkcjonują w środowisku uporządkowanym m.in. przez przepisy prawa. Poszanowanie obowiązującego prawa, a więc legalność praktyk stosowanych przez przedsiębiorstwo, zostało przyjęte w niniejszym tekście jako kolejne kryterium oceny moralnej. Takie stanowisko jest zbieżne z poglądami, jakie można odnaleźć w literaturze przedmiotu. Lin-Hi i Müller (2013), wyjaśniając, czym jest nieodpowiedzialność przedsiębiorstw, zauważają, że działanie społecznie nieodpowiedzialne wiąże się $\mathrm{z}$ łamaniem prawa, $\mathrm{z}$ drugiej jednak strony nie jest to warunek konieczny, aby uznać zachowanie firmy za nieodpowiedzialne, ponieważ przedsiębiorstwa mogą czasami stosować szkodliwe praktyki zgodnie z prawem, np. omijając je. Warto w tym miejscu dodać, że ostatnie badania pokazują, iż złamanie przepisów prawa przyczynia się do oceny czynu jako jeszcze bardziej szkodliwego, niż jest on w rzeczywistości (Nardella, Brammer, Surdu, 2020).

\section{Opresyjność}

Opresyjność to ostatnia cecha niemoralnego działania w modelu Haidta zaprezentowanym w pracy The Righteous Mind: Why Good People are Divided by Politics and Religion (2012). W teorii kodów moralnych opresyjność jest przedstawiona jako ograniczenie wolności jednostki (Haidt, 2012). Aby mogło ono występować, ktoś musi mieć władzę nad taką jednostką. Im większa jest ta władza, tym większa jest możliwość oddziaływania na podległą osobę lub organizację. Odnosząc opresyjność do przedsiębiorstw, warto zauważyć, że struktura zdecydowanej większości rynków znacząco odbiega od modelu konkurencji doskonałej, w której wszystkie podmioty gospodarcze mają taką samą siłę rynkową. Dodatkowo znaczące dysproporcje we władzy zazwyczaj istnieją między przedsiębiorstwem a jego interesariuszami. Na przykład taka różnica siły szczególnie widoczna jest pomiędzy pracodawcą a jego pracownikami, prowadząc m.in. do łamania praw słabszej strony (Sroka, 2018). Niemniej jednak nadużywanie siły przez przedsiębiorstwa może dotyczyć także innych interesariuszy, np. społeczności lokalnej, akcjonariuszy mniejszościowych czy dostawców (Hill i in., 2009).

\section{Metodabadań}

W części empirycznej niniejszego artykułu zaprezentowane są wyniki badań własnych, wktórych podjęto próbę przypisania praktyk społecznie 
nieodpowiedzialnych przedsiębiorstw do poszczególnych kodów moralnych. Ze względu na jakościowy charakter prezentowanych badań nie formułowano w nich hipotez badawczych.

Analizowane wyniki stanowią fragment pierwszego etapu badań, który miał na celu poznanie opinii konsumentów na temat tego, co traktują oni jako nieodpowiedzialne społecznie działania przedsiębiorstw. Jako metodę badawczą zastosowano zogniskowane wywiady pogłębione. Badania trwały w okresie czerwiec-październik 2020 roku. Przeprowadzono je we współpracy z Centrum Analiz Społecznych i Ekonomicznych KUL. W sumie w badaniach wzięło łącznie udział 100 respondentów w wieku 19-65 lat. Kobiety stanowiły połowę badanych. Wszystkie wywiady przeprowadzono zgodnie z ustalonym scenariuszem. Uczestnicy wyrazili zgodę na nagrywanie i zagwarantowano im anonimowość. W dalszej kolejności zarejestrowane wywiady zostały dokładnie spisane przez dwie osoby. W kolejnym kroku te same osoby, niezależnie od siebie, wybrały sformułowania odnoszące się do praktyk społecznie nieodpowiedzialnych przedsiębiorstw. Zgodność między nimi wyniosła $80 \%$.

Na kolejnych etapach prac podjęto próbę przypisania zidentyfikowanych praktyk do przedstawionych w poprzedniej sekcji kodów moralnych. Operacji tej dokonało czterech studentów, wcześniej odpowiednio przeszkolonych. Ich zadanie polegało na tym, aby każdą ze zidentyfikowanych praktyk przyporządkować do najbardziej pasującego kodu moralnego. Tabela 1 przedstawia opisy kodów moralnych opracowane na potrzeby wspomnianej operacji. Zgodnie z procedurą analizy treści (Krippendorff, 2009) każda z kodujących osób pracowała oddzielnie. Kolejno porównano uzyskane wyniki i rozstrzygnięto wspólnie, jak zakwalifikować praktyki, co do których występowały największe wątpliwości.

Tabela 1. Charakterystyka kodów moralnych wykorzystanych w badaniu

\begin{tabular}{ccl}
\hline Nr & $\begin{array}{c}\text { Nazwa } \\
\text { kategorii }\end{array}$ & \multicolumn{1}{c}{ Opis kategorii } \\
\hline 1. & Krzywda & $\begin{array}{l}\text { Działanie przedsiębiorstwa przynosi szkodę w sensie materialnym, fizycznym lub moral- } \\
\text { nym pewnej grupie ludzi lub organizacji. W szerszym ujęciu krzywdę można odnosić do } \\
\text { straty poniesionej przez całe społeczeństwo }\end{array}$ \\
\hline 2. Nieuczciwość & $\begin{array}{l}\text { Działanie przedsiębiorstwa jest nierzetelne, niesumienne lub niezgodne z prawdą (oszukań- } \\
\text { cze). Nieuczciwość może obejmować m.in. takie praktyki, jak: wprowadzanie w błąd, poda- } \\
\text { wanie nieprawdziwych informacji, manipulowanie, podawanie niekompletnych informacji }\end{array}$ \\
\hline 3. & Nielojalność & $\begin{array}{l}\text { Działanie przedsiębiorstwa cechuje brak troski o interesy osób i organizacji, z którymi jest } \\
\text { związane (pracownicy, klienci). Można powiedzieć, że brak lojalności przedsiębiorstwa } \\
\text { polega na swoistej zdradzie pracowników, klientów lub dostawców przez przedsiębiorstwo }\end{array}$ \\
\hline 4. Nieprawość & $\begin{array}{l}\text { Działanie przedsiębiorstwa jest niezgodne z przepisami obowiązującego prawa. Innymi } \\
\text { słowy - jest to działanie nielegalne, występek, przestępstwo }\end{array}$ \\
\hline
\end{tabular}




\begin{tabular}{ccc}
\hline Nr & $\begin{array}{c}\text { Nazwa } \\
\text { kategorii }\end{array}$ & Opis kategorii \\
\hline 5. Opresyjność & $\begin{array}{l}\text { Przedsiębiorstwo nadużywa swojej władzy w stosunku do osób i podmiotów, z którymi } \\
\text { jest związane. Dąży do podporządkowania sobie innych podmiotów, ograniczania ich } \\
\text { wolności }\end{array}$ \\
\hline
\end{tabular}

Źródło: opracowanie własne.

\section{Wyniki}

Uzyskane wyniki pokazują, że największy odsetek zgromadzonych stwierdzeń dotyczył niesprawiedliwości (tabela 2). Sugeruje to, że z perspektywy klienta nieodpowiedzialne praktyki przedsiębiorstw to działania, które osoba odbiera jako nieuczciwe. Szczegółowa analiza wypowiedzi uczestników badania wyraźnie pokazuje, iż zdecydowana większość ze wskazanych praktyk dotyczy sfery komunikacji rynkowej. Zakres dostrzeganej nieuczciwości w tym przypadku można wyrazić na pewnym kontinuum, poczynając od tworzenia zawiłych oraz trudnych do zrozumienia regulaminów, przez ukrywanie i pomijanie niekorzystnych informacji, a skończywszy na podawaniu całkowicie nieprawdziwych danych o produkcie. Warto zwrócić jeszcze uwagę na fakt, iż nie zostały wymienione nieuczciwe praktyki wobec innych grup interesariuszy, np. dostawców, pracowników czy państwa. W zasadzie wszystko dotyczy konsumentów, potwierdzając pośrednio spostrzeżenia innych badaczy, pokazujące, że działania przedsiębiorstwa skierowane do danej grupy interesariuszy są najważniejsze dla niej, natomiast sposób traktowania przez przedsiębiorstwo innych podmiotów jest mniej istotny (Mercer, 2003).

Tabela 2. Kody (nie)moralne i nieodpowiedzialne praktyki przedsiębiorstw w opinii respondentów

\begin{tabular}{ccc}
\hline Kod (nie)moralny & $\begin{array}{c}\text { Odsetek } \\
\text { stwierdzeń }\end{array}$ & \multicolumn{1}{c}{$\begin{array}{c}\text { Charakterystyczne przykłady nieodpowiedzialnych praktyk } \\
\text { przedsiębiorstw }\end{array}$} \\
\hline Nieuczciwość & $46 \%$ & $\begin{array}{l}\text { wprowadzająca w błąd reklama, składanie obietnic bez pokrycia przez sprze- } \\
\text { dawcę, ukrywanie ważnych informacji przed klientem, pisanie informacji } \\
\text { drobnym drukiem, niejednoznaczny opis produktu, manipulowanie pra- } \\
\text { cownikami, manipulowanie klientami (np. udawanie lekarza w reklamie), } \\
\text { podszywanie się pod inne produkty, używanie mylących nazw produktów, } \\
\text { wykorzystywanie niewiedzy klienta (pracownikab lub dostawcy), fałszowa- } \\
\text { nie raportów o produkcie, podnoszenie cen przed okresem promocji, zawiłe } \\
\text { i trudne do zrozumienia regulaminy, ukrywanie miejsca produkcji, niejasne } \\
\text { zapisy umowy, tworzenie nieprawdziwych (pozytywnych) opinii o produk- } \\
\text { cie w internecie }\end{array}$ \\
& \\
&
\end{tabular}




\begin{tabular}{|c|c|c|}
\hline Kod (nie)moralny & $\begin{array}{l}\text { Odsetek } \\
\text { stwierdzeń }\end{array}$ & $\begin{array}{c}\text { Charakterystyczne przykłady nieodpowiedzialnych praktyk } \\
\text { przedsiębiorstw }\end{array}$ \\
\hline Krzywda & $36 \%$ & $\begin{array}{l}\text { zmniejszanie wagi produktu przy pozostawianiu takiej samej ceny, stoso- } \\
\text { wanie szkodliwych składników, brak możliwości rozwiązania niepotrzeb- } \\
\text { nej umowy, sprzedaż przeterminowanych produktów, zaniżanie wartości } \\
\text { należnych świadczeń (np. ubezpieczeniowych), zawyżanie kosztów finanso- } \\
\text { wych, kradzieże oszczędności przez parabanki, niekorzystna zmiana składu } \\
\text { produktu (traci właściwości, obniża się jego jakość), skracanie cyklu życia pro- } \\
\text { duktu (np. telefon), podwyższanie rachunków, nieregularne płacenie wyna- } \\
\text { grodzeń, zaniżanie wynagrodzeń, brak możliwości większego zarobku (np. } \\
\text { godziny nadliczbowe), testowanie produktów na zwierzętach, łamanie prawa } \\
\text { do urlopu, wykorzystywanie pracowników z biedniejszych krajów }\end{array}$ \\
\hline Nielojalność & $9 \%$ & $\begin{array}{l}\text { nieuznanie słusznej reklamacji, niedotrzymywanie umówionych terminów } \\
\text { realizacji, nieprawidłowości w rozliczeniach z pracownikami, brak zapew- } \\
\text { nienia dobrych warunków pracy, zmiana składu produktu, wycofanie pro- } \\
\text { duktu z rynku }\end{array}$ \\
\hline Nieprawość & $5 \%$ & $\begin{array}{l}\text { nieprzestrzeganie praw pracowniczych, pobieranie innych cen przy kasie } \\
\text { niż „na półkach”, łamanie przepisów BHP, niepłacenie należnych podatków }\end{array}$ \\
\hline Opresyjność & $4 \%$ & $\begin{array}{l}\text { wymuszenia dotyczące niekorzystnych warunków zatrudnienia (umowy } \\
\text { śmieciowe), narzucanie zaniżonych cen przez koncerny, wprowadzanie zaka- } \\
\text { zów pracy u konkurencji }\end{array}$ \\
\hline
\end{tabular}

Źródło: opracowanie własne.

Kolejną grupą pod względem częstotliwości występowania są praktyki przedsiębiorstw, w których dostrzega się krzywdę wyrządzaną interesariuszom (30\% wypowiedzi). Pojawiająca się tutaj krzywda ma zazwyczaj charakter szkód majątkowych. Podobnie jak w przypadku nieuczciwości, praktyki w większości dotyczą relacji z klientami, a ich przejawem jest tzw. downsizing produktów, czyli zmniejszanie ilości sprzedawanego produktu przy niezmienionej cenie, obniżanie jakości produktów (np. w wyniku zmiany składu), skracanie cyklu ich życia czy nawet oferowanie produktów, których rażąco niski poziom jakości sprawia, że nie nadają się one do użycia (np. z powodu przeterminowania).

Nieodpowiedzialne praktyki przedsiębiorstw w rozpatrywanej grupie dotyczą także pracowników. Respondenci podają w tym przypadku m.in. takie działania, jak: zaniżanie wynagrodzeń pracowników, opóźnienia w ich wypłacie, niekorzystna organizacja czasu pracy, wykorzystywanie trudnego położenia pracowników w biedniejszych krajach. Odnośnie do praktyk powodujących niemajątkowe szkody badane osoby wskazały stosowanie szkodliwych dla zdrowia składników oraz testowanie produktów na zwierzętach. Co intersujące, w zarejestrowanych dyskusjach jedynie incydentalnie pojawia się kwestia środowiska naturalnego (np. wspomniane testowanie na zwierzętach), co może wynikać z odmiennego postrzegania kwestii społecznych i środowiskowych przez konsumentów (Catlin, Luchs, Phipps, 2017).

Pozostałe trzy kategorie społecznie nieodpowiedzialnych zachowań przedsiębiorstw, a więc związane z nielojalnością, nieprawością oraz opresyjnością, stanowią 
relatywnie nieznaczny odsetek. Do działań związanych z nielojalnością zaliczono takie praktyki, które klienci odebrali jako zdradę ze strony przedsiębiorstwa. Wymieniono tutaj niedotrzymywanie umówionych terminów realizacji umów, nieuznanie słusznej reklamacji, zmianę składu ulubionego produktu i, co ciekawe, wycofanie produktu z rynku, do kupowania którego przyzwyczaił się klient. Co do nieprawości uczestnicy prowadzonych dyskusji wskazali na łamanie przepisów bezpieczeństwa i higieny pracy, przepisów prawa pracy oraz prawa podatkowego. Odnośnie do praktyk, w których daje się zauważyć opresyjność przedsiębiorstw, wyróżniono przede wszystkim praktyki skierowane na innych interesariuszy niż klientów. W szczególności respondenci dostrzegli tutaj wykorzystywanie przewagi w stosunku do pracowników poprzez narzucanie niekorzystnych warunków pracy oraz wynagradzania. Konsumenci podali także nadużywanie siły rynkowej przez duże koncerny w stosunku do dostawców i konkurentów.

Opisując uzyskane wyniki, warto dodać, że podczas dyskusji mających na celu rozstrzygnięcie wątpliwości, do której kategorii ostatecznie daną praktykę zakwalifikować, wielokrotnie wskazywano na związki rozpatrywanej praktyki z kilkoma kodami moralnymi jednocześnie. Na przykład wprowadzające w błąd komunikaty reklamowe związane są przede wszystkim z nieuczciwością (oszukiwaniem). Nie mniej jednak ich konsekwencją może być podjęcie niewłaściwej decyzji przez konsumenta i doznanie przez niego krzywdy. Możliwe jest także, iż sama świadomość, że zostało się wprowadzonym w błąd może zostać odebrana jako szkoda o charakterze niematerialnym. Podobnie jest z praktykami, w których nielojalność jawi się jako wiodąca kategoria oceny niemoralnej. Przykładowo niedotrzymanie warunków umowy jest w pewnym sensie zdradą ze strony przedsiębiorstwa. Dla odbiorcy może oznaczać to zarówno szkodę, jak i przejaw nieuczciwości, oczywiście jeśli działanie takie będzie odebrane jako zamierzone. Analogiczne związki występują także w przypadku praktyk związanych w pierwszej kolejności z nieprawością czy opresyjnością. W ich przypadku również widoczne są odniesienia do innych kryteriów ocen moralnej. Szczególnie dostrzegalne są tutaj związki z krzywdą, której w węższym lub szerszym (społecznym) wymiarze można się doszukać.

\section{Dyskusja wyników}

Podczas dyskusji nad uzyskanymi wynikami zwrócono uwagę na implikacje teoretyczne, wnioski praktyczne oraz ograniczenia i kierunki dalszych eksploracji. Wyniki badań zaprezentowane w niniejszym artykule pokazują, że na gruncie teorii kodów moralnych można dokonać pewnego rodzaju przyporządkowania nieodpowiedzialnych praktyk przedsiębiorstw do kodów moralnych. Takie 
przyporządkowanie jest komplementarne w stosunku do rozpatrywania dzialań przedsiębiorstw ze względu na dotkniętą grupę interesariuszy (np. Swaen, Demoulin, Pauwels-Delassus, 2020) i może okazać się pomocne w lepszym zrozumieniu, w jaki sposób postrzegane są nieodpowiedzialne praktyki przedsiębiorstw przez interesariuszy.

Szczegółowe wyniki badań sugerują, że zdecydowana większość praktyk przedsiębiorstw wskazanych przez konsumentów jako społecznie nieodpowiedzialne wiąże się z tzw. tradycyjnymi kodami moralnymi, tj. z krzywdą i niesprawiedliwością. Co więcej, zarysowuje się tutaj pewnego rodzaju dysproporcja. W badaniach empirycznych zwykle rozpatruje się krzywdę wyrządzaną przez przedsiębiorstwa różnym grupom interesariuszy. Wyniki przeprowadzonych badań o charakterze eksploracyjnym sugerują, że główną cechą nieodpowiedzialnych praktyk przedsiębiorstw jest nieuczciwość, pojawia się ona jednak relatywnie rzadko w badaniach. Istnienie tej dysproporcji wskazuje, iż należy poświęcić więcej miejsca w literaturze przedmiotu konsekwencjom stosowania przez przedsiębiorstwa praktyk, które mają na celu oszukiwanie i manipulowanie klientami. Poza wymiarem etycznym tematyka ta posiada istotne znacznie ekonomiczne, co wyraźnie pokazują badania nad zawłaszczaniem wartości (Gulski, 2017a, 2017b) oraz funkcjonowaniem rynku żywności (Kowalska, 2016, 2019).

Zidentyfikowane zależności między wyznacznikami moralności działań przedsiębiorstw pokazują, że trudno jest bezkrytycznie przyjąć jedną z tez teorii kodów moralnych mówiącą o rozłączności kryteriów oceny moralnej (De Villiers-Botha, 2020; Gray, Schein, Ward, 2014). Uzyskane wyniki sugerują, iż nieodpowiedzialne praktyki przedsiębiorstw wiążą się z naruszeniem jednocześnie kilku norm moralnych. Wniosek taki potwierdzają także obserwacje krytyków teorii kodów moralnych. Na przykład po wnikliwej analizie wyników uzyskanych przez Haidta, Silvię H. Koller i Marię G. Dias (1993) Tanya De Villiers-Botha (2020) pisze, że wymienione wyniki wcale nie dowodzą, że wymiar krzywdy jest nieistotny przy ocenach moralnych, tylko obok oceny pod względem krzywdy występują jeszcze inne kryteria. Podobnego zdania jest Kurt Gray twierdzący, że w istocie rzeczy nie ma czynu niemoralnego, który nie powodowałby krzywdy, a wspomniana krzywda występuje z różną intensywnością w różnych postaciach (Gray i in., 2014).

Krzywda jako wspólny mianownik ocen moralnych nie oznacza jednak, że pozostałe kryteria są zbędne. Wiedza o tym, jakie specyficzne kody moralne związane są z nieodpowiedzialną społecznie praktyką przedsiębiorstwa może okazać się pomocna w identyfikacji uczuć powstających u odbiorców informacji o wspomnianych praktykach. Dostrzegana krzywda, jaką wyrządza interesariuszom przedsiębiorstwo, może wywoływać złość konsumentów wobec takiej jednostki 
(Antonetti, Maklan, 2016a) i współczucie wobec pokrzywdzonych (Antonetti, Maklan, 2016b). W przypadku zidentyfikowania nielojalności przedsiębiorstwa wzbudzonymi uczuciami konsumentów mogą być rozczarowanie i żal (Tsiros, Mittal, 2000; Zeelenberg, Pieters, 2004). Biorąc pod uwagę, że emocje są czynnikami istotnie kształtującymi zachowania konsumentów wobec nieodpowiedzialnych przedsiębiorstw (Antonetti, 2020), wiedza o kodach moralnych i emocjach może okazać się pomocna w pełniejszym zrozumieniu zachowań konsumenckich.

Wiedza o tym, które kody moralne są związane z poszczególnymi rodzajami praktyk nieodpowiedzialnych przedsiębiorstw, może mieć także znaczenie praktyczne. Jednym z obszarów jej zastosowania może być sfera komunikacji. Przekazy odwołujące się do moralności mogą być bardziej przekonujące niż wiadomości pozbawione argumentacji moralnej (Luttrell, Philipp-Muller, Petty, 2019). Na przykład organizacje niekomercyjne, planując kampanie informacyjne nawołujące do bojkotów nieodpowiedzialnych przedsiębiorstw, mogą w treści poszczególnych komunikatów odwoływać się do istotnych w danej sytuacji kodów moralnych. W świetle teorii kodów moralnych taka argumentacja może pomóc we wzbudzaniu emocji opinii publicznej, a w konsekwencji jej zachowań wobec przedsiębiorstwa.

Prezentowany tekst nie jest wolny od ograniczeń i słabych stron, które mogą stanowić jednocześnie inspiracje do dalszych badań naukowych. Wspomniane ograniczenia wynikają zarówno z przyjętych ram teoretycznych, jak i metody badawczej. Co do wykorzystanej teorii kodów moralnych, to, jak zaznaczono we wprowadzeniu, wyraża ona jedno ze stanowisk na temat kształtowania się ocen moralnych i nie jest wolna od uwag krytycznych. Warto więc w przyszłych publikacjach ukazać związki między społeczną nieodpowiedzialnością a innymi koncepcjami opisującymi sposób formułowania sądów moralnych. Szczególnie wartą do rozważenia wydaje się być teoria diad moralnych (Gray, Waytz, Young, 2012).

Przedstawione w niniejszym artykule badania miały charakter jakościowy. Ich wyników nie można w szerszej skali uogólniać na całą populację konsumentów. Jednak mogą one stanowić podstawę do dalszych badań, w rezultacie których będzie można określić intensywność oraz powszechność występowania zidentyfikowanych zjawisk. Poza przeprowadzeniem ilościowych badań wśród konsumentów warto także rozważyć realizację analogicznych badań wśród innych grup interesariuszy, aby przekonać się, czy z ich perspektywy większość nieodpowiedzialnych praktyk przedsiębiorstw także dotyczy krzywdy i oszukaństwa (nieuczciwości). Być może pracownicy będą w większym stopniu zwracać uwagę na praktyki związane z nielojalnością, ponieważ pozostają oni w dłuższych i bardziej zacieśnionych relacjach z przedsiębiorstwem niż klienci. Podobnie opresyjność może mieć większe znacznie dla pracowników, gdyż są oni w dużym stopniu uzależnieni od przedsiębiorstw. 
Podsumowanie

Celem prezentowanego artykułu było określenie relacji między nieodpowiedzialnością a niemoralnością działań przedsiębiorstw. Przeprowadzone badania pokazują, że na gruncie teorii kodów moralnych można dokonać pewnego rodzaju powiązania nieodpowiedzialnych praktyk przedsiębiorstw z normami moralnymi. Uzyskane wyniki sugerują, że nieodpowiedzialne praktyki wiążą się najczęściej z nieuczciwością i wyrządzaną krzywdą interesariuszom. W praktykach wskazywanych przez konsumentów jako nieodpowiedzialne relatywnie rzadko występują nielojalność, łamanie prawa i opresyjność. Wnioski z niniejszych badań mogą okazać się pomocne w dalszych pracach badawczych nad percepcją nieodpowiedzialnych praktyk przedsiębiorstw oraz reakcjami interesariuszy wobec nich.

\section{Bibliografia}

Antonetti, P. (2020). More Than Just a Feeling: A Research Agenda for the Study of Consumer Emotions Following Corporate Social Irresponsibility (CSI). Australasian Marketing Journal, 28(2), 67-70.

Antonetti, P., Maklan, S. (2016a). An Extended Model of Moral Outrage at Corporate Social Irresponsibility. Journal of Business Ethics, 135(3), 429-444.

Antonetti, P., Maklan, S. (2016b). Social Identification and Corporate Irresponsibility: A Model of Stakeholder Punitive Intentions. British Journal of Management, 27(3), 583-605.

Bianchi, E. C., Mohliver, A. (2016). Do Good Times Breed Cheats? Prosperous Times Have Immediate and Lasting Implications for CEO Misconduct. Organization Science, 27(6), 1488-1503.

Bloomberg (2015). Volkswagen Drops 23\% After Admitting Diesel Emissions Cheat. Pobrane z: https://www.bloomberg.com/news/articles/2015-09-21/volkswagen-drops-15-after-admitting-u-sdiesel-emissions-cheat (10.09.2021).

Campbell, J. L. (2007). Why Would Corporations Behave in Socially Responsible Ways? An Institutional Theory of Corporate Social Responsibility. Academy of Management Review, 32(3), 946-967.

Catlin, J. R., Luchs, M. G., Phipps, M. (2017). Consumer Perceptions of the Social Vs. Environmental Dimensions of Sustainability. Journal of Consumer Policy, 40(3), 245-277.

Clark, C. E., Riera, M., Iborra, M. (2021). Toward a Theoretical Framework of Corporate Social Irresponsibility: Clarifying the Gray Zones between Responsibility and Irresponsibility. Business \& Society, 00076503211015911. 
Darke, P. R., Ashworth, L., Main, K. J. (2010). Great Expectations and Broken Promises: Misleading Claims, Product Failure, Expectancy Disconfirmation and Consumer Distrust. Journal of the Academy of Marketing Science, 38(3), 347-362.

De Villiers-Botha, T. (2020). Haidt et al.'s Case for Moral Pluralism Revisited. Philosophical Psychology, 33(2), 244-261.

Ethical Consumer (2021). Ethical Consumer. Pobrane z: https://www.ethicalconsumer.org/ethicalcampaigns/boycott-amazon (15.09.2021).

Ferrell, O. C., Harrison, D. E., Ferrell, L., Hair, J. F. (2019). Business Ethics, Corporate Social Responsibility, and Brand Attitudes: An Exploratory Study. Journal of Business Research, 95, 491-501.

Goetz, J. L., Keltner, D., Simon-Thomas, E. (2010). Compassion: An Evolutionary Analysis and Empirical Review. Psychological Bulletin, 136(3), 351-374.

Graham, J., Haidt, J., Koleva, S., Motyl, M., Iyer, R., Wojcik, S. P., Ditto, P. H. (2013). Moral Foundations Theory: The Pragmatic Validity of Moral Pluralism. W: P. Devine, A. Plant (red.), Advances in Experimental Social Psycho$\log y$ (s. 55-130). San Diego: Academic Press.

Graham, J., Nosek, B. A., Haidt, J., Iyer, R., Koleva, S., Ditto, P. H. (2011). Mapping the Moral Domain. Journal of Personality and Social Psychology, 10, 366-385.

Gray, K., Schein, C., Ward, A. F. (2014). The Myth of Harmless Wrongs in Moral Cognition: Automatic Dyadic Completion from Sin to Suffering. Journal of Experimental Psychology: General, 143(4), 1600-1615.

Gray, K., Waytz, A., Young, L. (2012). The Moral Dyad: A Fundamental Template Unifying Moral Judgment. Psychological Inquiry, 23(2), 206-215.

Greenwood, M. (2007). Stakeholder Engagement: Beyond the Myth of Corporate Responsibility. Journal of Business Ethics, 74(4), 315-327.

Gulski, B. (2017a). Zawłaszczanie wartości jako czynnik zmian paradygmatu zarządzania. Kwartalnik Nauk o Przedsiębiorstwie, 44(3), 75-83.

Gulski, B. (2017b). Zjawisko zawłaszczania wartości a zachowania obronne przedsiębiorstw. Lublin: Wydawnictwo Uniwersytetu Marii Curie-Skłodowskiej.

Haidt, J. (2001). The Emotional Dog and Its Rational Tail: A Social Intuitionist Approach to Moral Judgment. Psychological Review, 108(4), 814-834.

Haidt, J. (2012). The Righteous Mind: Why Good People are Divided by Politics and Religion. New York: Random House LLC.

Haidt, J., Joseph, C. (2004). Intuitive Ethics: How Innately Prepared Intuitions Generate Culturally Variable Virtues. Daedalus, 133(4), 55-66.

Haidt, J., Koller, S. H., Dias, M. G. (1993). Affect, Culture, and Morality, or Is it Wrong to Eat Your Dog? Journal of Personality and Social Psychology, 65(4), 613-628. 
Hill, J. A., Eckerd, S., Wilson, D., Greer, B. (2009). The Effect of Unethical Behavior on Trust in a Buyer - Supplier Relationship: The Mediating Role of Psychological Contract Violation. Journal of Operations Management, 27(4), 281-293.

Hoi, C. K., Wu, Q., Zhang, H. (2013). Is Corporate Social Responsibility (CSR) Associated with Tax Avoidance? Evidence from Irresponsible CSR Activities. The Accounting Review, 88(6), 2025-2059.

Ingram, R., Skinner, S. J., Taylor, V. A. (2005). 'Consumers' Evaluation of Unethical Marketing Behaviors: The Role of Customer Commitment'. Journal of Business Ethics, 62(3), 237-252.

Jones, B., Bowd, R., Tench, R. (2009). Corporate Irresponsibility and Corporate Social Responsibility: Competing Realities. Social Responsibility Journal, 5(3), 300-310.

Kim, S., Krishna, A., Dhanesh, G. (2019). Economics or Ethics? Exploring the Role of CSR Expectations in Explaining Consumers' Perceptions, Motivations, and Active Communication Behaviors about Corporate Misconduct. Public Relations Review, 45(1), 76-87.

Kowalska, A. (2016). Problem fałszowania żywności w Polsce. Problemy Jakości, 48(9), 28-35.

Kowalska, A. (2019). Ekonomiczne problemy fałszowania żywności. Instrumenty przeciwdziałania. Lublin: Wydawnictwo Uniwersytetu Marii Curie-Skłodowskiej.

Krippendorff, K. (2009). The Content Analysis Reader. Los Angeles: Sage.

Lange, D., Washburn, N. T. (2012). Understanding Attributions of Corporate Social Irresponsibility. The Academy of Management Review, 37(2), 300-326.

Lin-Hi, N., Müller, K. (2013). The CSR Bottom Line: Preventing Corporate Social Irresponsibility. Journal of Business Research, 66(10), 1928-1936.

Luttrell, A., Philipp-Muller, A., Petty, R. E. (2019). Challenging Moral Attitudes With Moral Messages. Psychological Science, 30(8), 1136-1150.

Mena, S., Rintamäki, J., Fleming, P., Spicer, A. (2016). On the Forgetting of Corporate Irresponsibility. Academy of Management Review, 41(4), 720-738.

Mercer, J. J. (2003). Corporate Social Responsibility and Its Importance to Consumers. Philadelphia: Claremont Graduate University.

Nardella, G., Brammer, S., Surdu, I. (2020). Shame on Who? The Effects of Corporate Irresponsibility and Social Performance on Organizational Reputation. British Journal of Management, 31(1), 5-23.

Oh, W. Y., Chang, Y. K., Jung, R. (2018). Experience-Based Human Capital or Fixed Paradigm Problem? CEO Tenure, Contextual Influences, and Corporate Social (Ir)Responsibility. Journal of Business Research, 90, 325-333. 
Pawlak, M. (2018). Poziom moralności przyszłych liderów biznesu - międzynarodowe porównania. Zeszyty Naukowe Politechniki Poznańskiej. Organizacja i Zarzadzanie, 78, 151-167.

Pawlak, M. (2019). Moralność i religijność przyszłych liderów biznesu. Wyniki badań z wykorzystaniem hierarchii wartości. W: M. Pawlak (red.), Nowe tendencje w zarzadzaniu (t. 8, s. 29-50). Lublin: Wydawnictwo KUL.

Payne, D., Pawlak, M., Mahesh, S. (2018). The Moral Development Index of Future Business Leaders: A Study on the Impact of Changes in Economic Systems and Gender. Journal of Business and Management, 24(1), 49-78.

Pearce, C. L., Manz, C. C. (2011). Leadership Centrality and Corporate Social Ir-Responsibility (CSIR): The Potential Ameliorating Effects of Self and Shared Leadership on CSIR. Journal of Business Ethics, 102(4), 563.

Schein, C., Gray, K. (2018). The Theory of Dyadic Morality: Reinventing Moral Judgment by Redefining Harm. Personality and Social Psychology Review, 22(1), 32-70.

Sousa, P., Piazza, J. (2014). Harmful Transgressions qua Moral Transgressions: A Deflationary View. Thinking \& Reasoning, 20(1), 99-128.

Sroka, R. (2018). Samoregulacja biznesowa w zakresie etyki biznesu firm zachodnich jako odpowiedź na łamanie praw pracowniczych w Chinach. Człowiek i Społeczeństwo, 46.

Swaen, V., Demoulin, N., Pauwels-Delassus, V. (2020). Impact of Customers' Perceptions Regarding Corporate Social Responsibility and Irresponsibility in the Grocery Retailing Industry: The Role of Corporate Reputation. Journal of Business Research.

Tsiros, M., Mittal, V. (2000). Regret: A Model of Its Antecedents and Consequences in Consumer Decision Making. Journal of Consumer Research, 26(4), 401-417.

Windsor, D. (2013). Corporate Social Responsibility and Irresponsibility: A Positive Theory Approach. Journal of Business Research, 66(10), 1937-1944.

Yuksel, U., Mryteza, V. (2009). An Evaluation of Strategic Responses to Consumer Boycotts. Journal of Business Research, 62(2), 248-259.

Zeelenberg, M., Pieters, R. (2004). Beyond Valence in Customer Dissatisfaction: A Review and New Findings on Behavioral Responses to Regret and Disappointment in Failed Services. Journal of Business Research, 57(4), 445-455. 
